\title{
A home for all: The story of the inversion of hospitality in Genesis 19
}

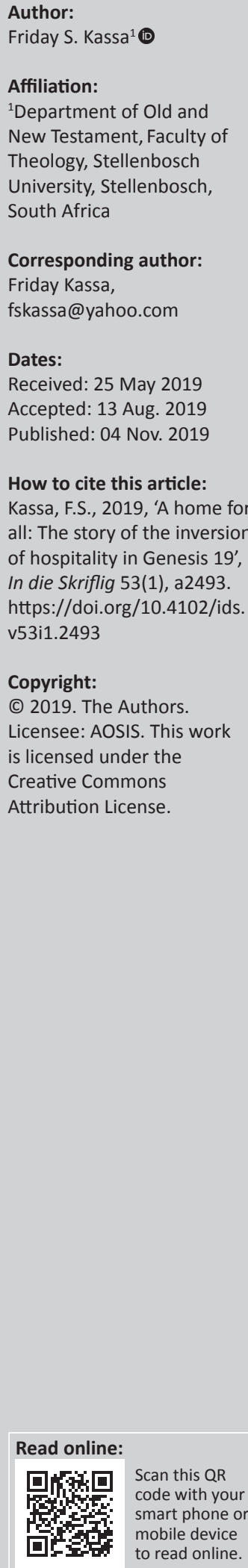

\begin{abstract}
This article is a theological-ethical reading of the narrative of Lot's hospitality in Genesis 19, using the hermeneutical lens of a Christian faith tradition. It considers hospitality as a living existential struggle that has crucial contemporary implications. The article poses the question: How do we see the arrival of 'the other' into our so-called 'private and secure territory'? It then attempts a response to the question from the inversion of hospitality's point of view and its resultant effects.
\end{abstract}

Keywords: Hospitality; Lot; Sodom; Wickedness; Genesis 19; Narrative Criticism.

\section{Introduction}

Memories of childhood are something this writer longs to relive. One can remember vividly, as a child, the longing for guests to visit the family. A stranger in the home means a change of meal (rice and stew) or, at least, the guarantee of a piece of meat as part of the meal. The writer is talking about a semi-urban setting and a period when there was a high influx of strangers, mostly Hausa and Fulani traders, in their community. Friendships were usually established between these strangers and the young boys (teenagers) who would render their services to the strangers, assisting in setting up their stalls and sales of groceries. Such friendships with strangers did not end in the market square. Often, some of these traders would miss their only transport back home, which meant they had to wait until the following day to leave. The traders would then be invited into the home of their young friends to be hosted for the night. Upon arrival at the house, the stranger was welcomed warmly by the boy's parents and offered food, as well as a comfortable room to sleep.

Things have since changed. Most of the semi-urban communities are now developed and presumably civilised, and the story is different. One would expect that with modernisation and the advancement in technology and economy, and what is supposedly a better life, the practice of hospitality to strangers should also be enhanced. However, the opposite is the case. One dares not to trust anyone. Communities have become xenophobic, especially in light of the current global challenges of insecurities. The current situation in Nigeria is alarming. Communities and villages are wiped out for reasons unknown, and such cruelties are often justified even by top government figures as reprisals. The intention of this article is to challenge readers to be sensitive to the dynamics of the global society era.

This article presupposes the relevance of the church in the search for an appropriate and peaceful response to the world's calamity. It is intended to serve as a clarion call to the Christian church, to act as the ethical mirror to the ongoing social ills such as religious conflict, ethnic and tribal conflict, political violence and oppression, injustice, and economic and political instability. The article seeks a Christian response in a situation where people are exposed to insecurity because of the presence of the 'other'. It argues that the value of hospitality, as an ethical category for modern ethical concerns, cannot be overemphasised, especially as it relates to refugees, immigrants, issues of welfare, justice and fairness, among others. The story of Genesis 19 is used as a case study of the absence of hospitality and its possible impact. The article shall first provide an overview of hospitality within the Semitic culture of the Old Testament times, because it is the cultural context from which the texts were written. The overview is then used as a point of departure for understanding Genesis 19 , especially as it relates to the parallel story of Abraham's story of hospitality in Genesis 18.

\section{Hospitality in the context of Semitic cultures}

The article is limited in terms of space to discuss in-depth the ancient Near Eastern literature and non-literary documents such as iconographies of the ancient Near East that deal with the subject of hospitality. Suffice it to say, the practice of hospitality was a vital part of the ancient Semitic world's culture (cf. Pardee 2003:344 ff.; Shryock 2004:34-62). 
Scholars attest to the fact that hospitality is celebrated among the ancient Semites, as having profound value (cf. Carr 2011; Hobbs 2001:3-30). It was crucial in the private exchange of ideas, as well as in the context of international relations (Pezzoli-Olgiati 2009:261). The 'exchange of ideas' underlies the principle of reciprocity, which often formed the basis for an alliance between the guest and the host. Hospitality in the ancient Semitic world, sprang from the need for protection when travelling, as travellers in the ancient world were very vulnerable to the extremely harsh environment and actions of roaming robbers. Moreover, travellers had little, if any, legal or political rights. As such, the practice of hospitality was the only means of ensuring their protection (Dell 2009:261). Although the need to protect the stranger prompted the custom of hospitality, the practice shows that it was also a mutual responsibility where both the host and stranger cooperated in sharing:

The host protects the guest from the numerous perils to which he or she is exposed in his precarious status and guarantees his livelihood for a limited span of time; the guest accepts hospitality without exploiting the host (Pezzoli-Olgiati 2009:260).

Genesis 18-19 is one of the biblical texts on hospitality, and it presents two parallel and similar stories in which divine beings were hosted. This article focuses on the inversion of the practice of hospitality in Genesis 19, and it employs the narrative discourse (criticism) ${ }^{1}$ as the style of reading.

\section{'Do not do such an evil thing': A narrative discourse of Genesis 19}

Firstly, a brief background issues to the passage: The question of the dating of the Pentateuchal text is nowhere near a consensus. The debate is still on, as there are varying opinions. For example, one opinion suggests that the narrative under study was composed during the pre-exilic period, precisely during the reign of King David (2 Sm 5). Canaan was for the first time under the firm control of Israel, and it constituted a political entity among the nations of the world of that time (Fretheim 1977:305). On a slightly different note, Westermann (1985:300) suggests that Genesis 19 'has its origin in the period of the Israelite transition to city dwelling; the story reflects the experience of crime made possible by city life $[\ldots]^{\prime}$. According to him, this development (transitioning) brought with it several changes. There was a radical change in the structure of Israelite society. Power shifted from tribal rule to a more centralised rule under the monarchy. Traditional culture was quickly giving way to the urban culture that was characterised by affluence, economic

\footnotetext{
1.Robinson (2007:237) explains narrative criticism thus: 'Narrative criticism of biblical texts is the hermeneutical endeavor that seeks to understand the various factors that combine for a close reading of a text's narrative world without being arbitrary and subjective. Narrative criticism attempts to appreciate the aesthetic nature of stories as both a literary and historical concern within the larger context of the stories or books themselves rather than isolated segments on their own' This article stories or books themselves rather than isolated segments on their own.' This article does not endeavour to cover in detail all that constitutes a narrative reading (e.g. critical study of the plot or storyline, character(s), narrator's role, time, etc.), especially for a large pericope as this within an article that is limited by space. The article considers briefly some of the narrative features of the text. It assumes a close reading through dynamic synchrony of synchronic and diachronic hermeneutical lenses. The article focuses on stylistic structure at the level of storytelling (see Lawrie 2005:96 ff. Westfall 2007:237).
}

planning, diplomatic shrewdness and military calculation. Although Israel was stable in that period, it was faced with the challenge of relevancy amidst an entirely new era and situation. The traditions that had served the people well, suddenly seemed obsolete. The question at hand was how to be faithful to these traditions, and remain relevant in the contemporary situation. Recently, Arnold (1998:179) and Matthews $(2005: 209,211)$ decided to be neutral concerning dating Genesis. They summit that Genesis is a composite text. The text in its final form must have gone through various stages and are preserved by priests and scribes, and that several elements points to the exile period and beyond.

This research holds that siding with a specific view on dating, might not necessarily change the assumed motif of the redactor of the narrative. There seems to be a basic theological quest that is not altered by the time of composition. The narrator or redactor seems to be interested in reminding the community of Israel, which was politically independent and economically stable, of the importance of the traditional ethos of hospitality as the expression of covenant faithfulness to the 'way of Yahweh', which is 'righteousness and justice' (Gn 18:18), to the social stability of the community.

The compiler achieved his theological intent by combining various smaller units of traditions into one larger story (Gn 18-19) within the Abrahamic narrative cycle (Gn 12-25), anchored in the motifs of the promise of land and of prosperity (cf. Westermann 1985:124ff.). The question that this article asks is what the significance is of these stories in the Abrahamic narrative and the stated motifs.

It is noteworthy that the promise of land and of progeny in the narrative is anchored in God's covenantal relationship. In the larger literary unit of the selected pericope, Genesis 18:17-19 states the condition for the maintenance of the relationship. In Yahweh's soliloquy, the narrator of the story presents Yahweh's thoughts, contemplating whether he should hide from Abraham what he was about to do (Gn 18:17). Yahweh reflected on his promise as a basis not to conceal from Abraham his intention (Gn 18:18). ${ }^{2}$ Then Yahweh continues in verse 19, stating the covenant response as the purpose of electing Abraham thus:

Kî yedăă tîw lemă ăn 'ǎšěr yeșăwwěh 'ẹt-bānāyw we' ět-bêttô 'ăhărāyw wešāmerû děrěk Y YHWH lă ǎšôt ședāāāh ûmišpāt lemǎ ǎn hābîi’ YHWH 'ăl-'ăbrāhām 'êt 'ǎšěr-dibběr 'ālāyw [For I have chosen him, in other that he will command his sons and his family after him and they will keep the way of Yahweh by doing righteousness and justice so that

2.The constituent structure of the verse is fronted and begins with the conjunction waw (1). Waltke and O'Connor (1990:650) observe that ' $[i]$ nterclausal waw before a non-verb constituent has a disjunctive role'. They identified two roles for the disjunctive waw as continuity of scene and change of action. In this case, one could see that the disjunctive clause continues the scene by stating the reason why God should not hide his intension from Abraham; thus the disjunctive waw is possibly causal in its syntactical relationship. (cf. Note on Genesis 18:18 from The NET Bible, 2005:49).

3.yedă tîw literally means, 'I have known him'. The root word, yedă, has other semantic potentials as 'notice, observe, find out, recognize, perceive, care about, be concerned about, be(come) acquainted with, experienced, have intercourse with, select, choose, understand something, be able to distinguish between, have insight, judgment' (Köhler et al. 1994:391). The NET Bible First Edition Notes (2006), notes that the verb yedă here means 'to recognize and treat in a special manner, to that the verb yedă here means 'to recognize and treat in a special manner, to
choose' (see Am 3:2). It indicates that Abraham stood in a special covenantal relationship with the Lord. 
Yahweh will bring to Abraham that which he spoke to him. (author's own translation)]

The language of the story (Gn 18-19) reveals contrasting motifs between the two hospitality stories. One could deduce that the incident, which is described as evil $\left(r \bar{a}^{\prime} \check{a}^{\prime}\right)$ in our selected pericope (Gn 19:7), shows contrast to righteousness (șed $\underline{a} q \bar{a} h)$ and justice (mišpa $\bar{t}$ ), the demand of the covenant responsibility. Ultimately the contrast shows the fate of the righteous and of the wicked in this world exemplified by the survival of the two hospitable families (Abraham's and Lot's), contrasted with the destruction of inhospitable people of Sodom and their fertile planes (cf. Noort 2004:5). ${ }^{4}$ The story of the inhospitality of Gomorrah, which the narrator deftly calls an 'evil thing' through the mouth of Lot, is the focus of this article. What does the writer aim to achieve?

Genesis 19 continues the narrative that began in Genesis 18, which was obstructed by Genesis 18:23-33. It begins with the arrival of the two angels who had left Abraham and Yahweh standing in Genesis 18:22 at the gate of Sodom. Following the arrival is a short parallel story of hospitality to the two messengers - reminiscent of Abraham's - performed by Lot (Gn 19:1-3). The intention of the narrator can be seen in the terseness of the story, which does not suggest lesser practice as some interpreters assume (see Safren 2012:163ff.), rather to shift the focus of the readers to his theological and ethical intent.

The narrator quickly turns his attention to painting the picture of the dismal and unwelcoming behaviour of 'the men of Sodom'. Genesis 19:4 says:

Before they lie down to sleep, the men of the city, the men of Sodom, surrounded against the house, from young to the old. All the people to the last. (author's own translation)

He uses the Hebrew preposition, 'ăl, prototypically translated as 'upon', which indicates a spacial position. The 'ăl in this construction expresses intention as in war, and can be translated as 'against' (cf. Köhler et al. 1994:825). ${ }^{5}$ The narrator was ambiguous in his expression of the intension of the people for their demand, to bring the people to them so that they will know them. However, the situation described here is not that of a friendly welcome and brief interrogation. The 'coming against the house' is later described as an 'evil thing' (Gn 19:7) in the words of Lot. There is a tension here regarding the matter of civic responsibility. Who is responsible

4.With this conclusion, one could draw from it that the zeal for the justice of God which guarantees that the just are not treated like the wicked, could be regarded as one of the motifs used by the redactor. It shows Abraham's hospitality, as a righteous act and the lack of hospitality as wickedness. Righteous living expedites the fortun of Abraham's posterity, while wickedness impedes the posterity of the people of of Abraham's posterity, while wickedness impedes the posterity of the people of Sodom. Thus, situating the story within the Abrahamic narrative could be for the posterity.

5.Other semantic possibilities show that could be used to indicate the goal of a process' in joining together of entities' used to imply specification and cause. Its use process' in joining together of entities' used to imply specification and cause. Its use
in Genesis 19:4 indicates intention or goal, especially since the verb stem, nāsăbbû,, is in the nifal, meaning to 'turn oneself against' (cf. Waltke \& O'Connor 1990:216ff.) for these strangers? It is expedient that the article zooms in its lens on Lot and the men of the city - so that one will get a feeling of the tension and understand the possible motive of the narrator.

\section{Lot $-\mathrm{A}$ resident alien}

The writer places Lot in a strategic position - he was sitting at the gate. He no longer lived in a tent (Gn 13:12), but he is now an urban man residing in the city, and he had possibly assumed some civic responsibility as a citizen. By virtue of being at the gate, one could assume that Lot had won a measure of acceptance by the citizens of Sodom, and he was probably one of the dignitaries in the city (Waltke \& Fredricks 2001:275). In fact, Lot addresses the men as 'brothers'. Regarding being at the gate, Von Rad (1972:217; cf. Matthews 1992:4; Waltke \& Fredricks 2001:275) comments that 'during the day the gate served as a court and a market' (cf. Rt 4:1; 2 Ki 7:1). Therefore, one may assume that it was one of Lot's civic responsibilities to provide hospitality in a sophisticated and civilised society like Sodom and Gomorrah. Ironically, while Lot addresses the men of Sodom as brothers, Genesis 19:9 shows that the men of Sodom did not consider Lot as one of them. Their statement, 'this man has come as an alien ... and now he wants to play the judge' could probably mean that Lot had overstepped his boundaries. The questions one may ask, are whether Lot was sitting alone at the city gate when these visitors arrived in the evening. Was there no one to welcome these visitors at the time of their arrival? Lot was probably not alone, but it seems that he alone cared and noticed the strangers, greeted them and then invited them to his house because it was already dark. Lot's social status in Sodom must have given him the confidence to invite these visitors into his house.

Was Lot overstepping his boundaries as Matthews (1992:4) suggests? Probably not. According to Blenkinsopp (2015:131), '... visitors customarily waited at the city square until the city offered hospitality in the person of one of its citizens'. Considering what had transpired at the gate, neither Lot nor the strangers broke the ancient custom of asking and offering hospitality. The city gate, as noted above, equally served as a city square, 'meeting places in ancient cities' (McKeown 2008:106). Von $\operatorname{Rad}(1972: 217)$ describes the place as a 'thoroughfare ... where men were accustomed to gather in the evening'. The skilful pen of the narrator paints a different picture for the reader, a different scene from that at Hebron. Unlike their visit to Abraham at Hebron, here their mission was for the city, not to Lot. They appeared at the city gate, but only Lot seems to show concern for the strangers. He was insistent and they acquiesce. The conversation between Lot and the strangers, as Blenkinsopp (2015:131) remarks, is in line with the customary procedure in the ancient Semitic world for asking and offering of hospitality (cf. Jdg 19:10-21).

Reading the parallel story of the Levite and his concubine at Gibeah, one would argue that Lot had already known his 'brothers', and that is why he pressured them to be under his roof. Concurring with this position, Waltke and Fredricks (2001:275) observes that this: 
Interpretation is confirmed by the events that follow, by his instruction that they can be on their way early in the morning $\left[{ }^{6}\right] .$. and by parallel incident of the Benjaminites at Gibeah. There too the host, an old man, cautions his guest about the peril of spending the night in the city square of the evil place. (Jdg 19:18-20)

\section{The men of Sodom}

The event at Sodom and Gomorrah has elements of great potential of insecurity that could lead to the loss of the right of ownership and other related rights and freedoms. There was a great potential for the breach of security in the land of Sodom and Gomorrah. Lot was an 'alien' who had enjoyed the long-term hospitality of Sodom. From a modern point of view, one may possibly understand the actions of the men of Sodom as a normal act of diplomatic policies. In this regard, the crucial questions are: Should Sodom's act of generosity to an alien, Lot, be allowed to go unchecked? Should one blame the men of the city for placing strictures on their diplomatic policies because of practical realities? ${ }^{7}$ But that is not the real picture painted by the narrator. The issue in Lot's case is not even that of diplomatic policies. It is that of the wickedness of the entire city, demonstrated by the mob injustice of all the men, young and old.

Elsewhere in Genesis 13:13, the reader was already prompted by the narrator concerning the wickedness of the city of Sodom. In Genesis 18:22-32, Abraham pleaded with the Lord to spare the city for the sake of 10 righteous people. Ten righteous people were not found. In Genesis 19:4, the narrator skilfully alluded to this conversation when he says:

Before they lie down to sleep, the men of the city, the men of Sodom, surrounded against the house, from young to the old. All the people from the end of the city. (author's own emphasis)

The narrator introduces the men of Sodom in vers 4 , creating an emotional tension in the mind of the reader. We have already noted the ambiguity employed by the narrator in expressing the intentions of the men of the city. The difficulty one encounters here is seen in the history of theologicalethical interpretation - trivialising the so-called sin of Sodom. ${ }^{8}$ However, what is described in the passage is a

6.This writer differs with Waltke on the secrecy of the coming in and out of the strangers into the city. According to him, Lot's instruction is presumably so that they can slip in and out of the city unnoticed'. The strangers were already at the city gate, reading Lot's instruction in a way that would suggest that Lot had not followed the right procedure. But as the story later revealed (Gn 19:4), the coming in of the strangers was not a secret - the men of the city were aware. Lot's instruction should strangers was not a secret - the men of the city were aware. Lot's instruction should be understood as a normal way of persuasion and warning of the danger at night. It was already evening, and the strangers should lodge in so that in the morning they will be a time of danger' (Letellier 1995:59).

7.There is no doubt that insecurity, scarce resources, inadequate infrastructure and social amenities are a genuine reason for any government to put strictures on its policies regarding international relations. The absence of such policies would spell doom for any country that gives in to the flowery and appealing description of what unconditional hospitality promises.

8.The history of interpretation reveals that some scholars focus on, or look for the one sin of Sodom. A certain group of scholars such as Gunkel (1917), Von Rad (1972), Westermann (1985) and Towner (2001) all assume that the sin, which led to the destruction of Sodom and Gomorrah, is uncontrolled human lust and violence, or homosexual lust. Others such as Boswell (1980), Matthews (1992) and Fields (1997) view inhospitality as the main sin of the people of Sodom. To them male-male sex or rape was only a basis for inhospitality. The third group of scholars considers the Genesis 19 episode as an act of shaming (cf. Bailey 2010). However, Loader (1990) Hamilton (1995) and Blenkinsopp (2015:132ff.) argue that social and sexual immorality cannot be separated. Blenkinsopp draws a parallel between the incident immorality cannot be separated. Blenkinsopp draws a parallel between the incident
at Sodom and the crime at Gibeah which, he says, relate to both hospitality and gruesome inhuman treatment, which violates Yahweh's covenantal demand for righteousness and justice. Robinson (2007) observes that biblical narratives:

... should not be hastily classified, defined or thematically categorised ... Narratives do not consist of set of doctrines or propositions for normative guidance in life and belief but present us with rich stories which the reader can participate. (p. 236)

This article cautions against reducing the sin of Sodom to one specific act as if that is the only thing the narrative seeks to offer.

\section{Inhospitality as evidence of wickedness}

The inhospitality of the men of Sodom entails more than just a lack of welcome and offering an elaborate meal. It has to do with moral depravity and violation of human dignity. An intertextual investigation of the occurrence of Sodom in the Old Testament provides a broad view of how the incident of Sodom should not be trivialised to one specific sin or the other. The occurrences of Sodom and Gomorrah often occur as paradigms of depravity, corruption and destruction (Is 1:4, 9-10, 17; 3:9; 13:19; Jr 23:14; 49:18; 50:40; Ezk 16:48; 16:49; Am 4:11; Zph 2:9; cf. Blenkinsopp 2015:130, n24).

Obviously, Lot is the one that is giving hospitality here. Like Abraham, he went to the men and invited them to his house, persuading them to turn aside into their 'servant's' house to spend the night and get refreshed. Lot would not allow them to pass the night out there in the open place as they opted. Rather, he urged them until they gave in and 'went into his house, and he prepared a meal for them and baked bread and they ate' (Gn 19:3). However, there is great irony as the story unfolds. Lot had good intentions by protecting these strangers from dangers in the open place. He even endangered himself by going out of the door and shutting the door behind him to plead with the people 'not to do such a wicked thing' (Gn 19:6-7, 9-10). It does not end there. Lot, like the people of the city, resorted to proposing a gruesome, hideous, horrible violation of the dignity and right of his only two daughters 'who have not known a man'. He offered his daughters to the men as hostages to guarantee the safety of the guests. Reading the parallel story of the crime at Gibeah in Judges 19, gives a hint of what possibly could happen to Lot's virgin daughters if it were not for the intervention of the divine strangers.

The story portrays Lot as a desperate man who was willing to go to any extreme - even sacrificing his own life or that of his daughters in order to protect his guests. This is not only a typical example of an act of male chauvinism; it is also a

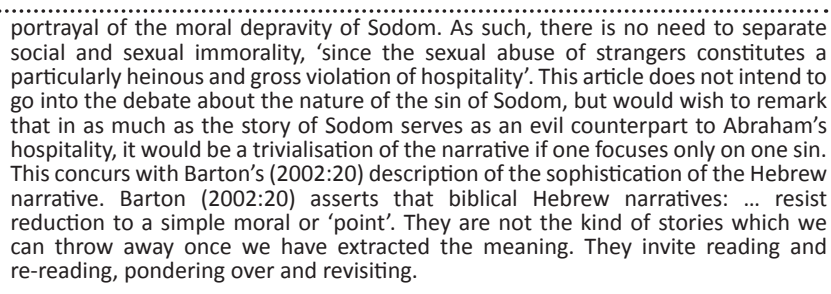
social and sexual immorality, since the sexual abuse of strangers constitutes particularly heinous and gross violation of hospitality' This article does not intend to go into the debate about the nature of the sin of Sodom, but would wish to remark that in as much as the story of Sodom serves as an evil counterpart to Abraham's hospitality, it would be a trivialisation of the narrative if one focuses only on one sin. This concurs with Barton's (2002:20) description of the sophistication of the Hebrew can throw away once we have extracted the meaning. They invite reading and re-reading, pondering over and revisiting. 
reflection of the value system of Sodom and Gomorrah - a value system that says that a certain class of people have less dignity than the other and could be treated unjustly and deprived of their dignity. It is a value system that says that one's worth depends on others' worth, and forcefully dispossesses one of what is precious to them. One struggles to understand the significance of Lot's action, even within the context of the protection of his guests. ${ }^{9}$

Hospitality does not and cannot justify Lot's action. The nobility of his intentions is dulled by his willingness to surrender his daughters to the fury and lust of the mob surrounding his house. Lot's action can be understood as the willingness to compromise the standard of righteousness and justice, to appease an ungodly behaviour, 'the wicked thing' of Sodom. Later in the story, one finds Lot's daughters also stooping down to commit incest with their father as evidence of their acceptance of the morals of Sodom and Gomorrah. ${ }^{10}$

\section{Conclusion}

The violation of the strangers' right to protection is a serious crime. Inhospitality ${ }^{11}$ is not just a denial of food and shelter, it expresses the inhumanness in the heart of the one denying it. ${ }^{12}$ Denying a stranger of food and shelter is an indication of gross depravity and wickedness in the heart. The violation of the right to protection is a serious crime against not only the guest, but also in a sense the whole of humanity, as it threatens the whole human community. In Lot's case, because the messengers and even Lot himself were temporary residents, it was assumed that they had no equal rights before the law. The crime against the messengers took the form of attack in which the attackers assumed absolute superiority, which prompted them to give free rein to their wickedness (see Westermann 1985:301)

9 .Waltke and Fredricks (2001.274) summarise the irony in the narrative thus: 'Lot tries to be a bltizen, as a husband, as a father. He wants to protect his guest but ne a citizen, as a husband, as a father. He wants to protect his guest but needs to be protected by them, he tries to save his family, and they think he is joking; afraid to journey to the mountains, he pleads for a little town, but afraid of the town, he flees to the mountains.

10.This article is not judging Lot's daughters here; the narrator never did that. He was simply reporting the event. In fact, one finds that later in history one of the sons of Lot's daughter became an ancestor of both David and Jesus, that is, Ruth the Moabitess (Rt 4:18-22; Mt 1:5). However, the narrator deftly judges the morality of their behaviour by making their decision to correlate with their father's earlier abuse - giving them to the Sodomites to do as they wished with them. Lot was the one who initiated that act of unconsented sex. One may say that, 'it is a matter of preserving the (human) family after the disaster (vv. 32, 34b)' (Westermann 1985:312) This is not what this article seeks to discuss, although it is helpful to point 1985:312). This is not what this article seeks to discuss, although it is helpful to poin out that the Hebrew scripture later condemns incest (Lv 18:6-8; 20:11-12, 17 19-21; Dt 22: 30; 27:20-23; Ezk 22:11; cf. 1 Cor 5:1). The ambiguity of the text also allows the reader to make such a judgement. However, what seems clear from the kilful pen of the narrator is the reversal of the action of Lot against his daughters by the daughters themselves. This is what nullifies the honour of the preservation of the family line as they claimed. Lot's daughters were their own judges. The fact that they had to connive to make their father drunk and to sleep with him without him knowing, shows that they themselves, in one way or the other, also questioned the morality of their action.

11.The Bible instructed the Israelites to be hospitable to foreigners because of their background as foreigners in Egypt (Ex 22:21; Lv 19:33-34). Speaking of the significance of hospitality, Bosman (2018:571-590), interprets 'Loving the neighbour and the resident alien in Leviticus 19 as ethical redefinition of holiness'. Lack of hospitality by other nations is condemned in the Old Testament (Nm 20:1421; Dt 23:2-3).

12.Although Westermann (1985) has warned against moralising the narrative, this Although Westermann (1985) has warned against moralising the narrative, this narratives, as noted above, resist being reduced to a simple point. However, due to the gravity of the sin of inhospitality explicated in Genesis 19, one may find it the gravity of the sin of inhospitality explicated in
difficult not to look for moral elements in the story.
The wickedness and evils, as portrayed in this narrative, have remained one of the greatest human problems over the ages. One could recall the Holocaust in Nazi Germany, the fate of the black people, mixed race people and Indian people in the South African apartheid era, or the fate of the people with darker skin colour in the United States during and after slavery. Violation of human rights and continued exploitation of the voiceless are found in various forms in different countries of the world. One could also mention the current and frequent xenophobic attacks in South Africa, the exploitation of refugees in Europe and America and gruesome killings of people in Nigeria by terrorist groups, Boko Haram and the Fulani herdsmen.

It is also important to draw attention to the fact that humanity lives in an increasingly pluralistic, multi-faith society. To welcome a stranger, means breaking the boundaries of one's comfort zone and obstruction of established relationships; therefore it is a risk. Migration has become a pint on the security agenda in many nations due to the increase in the number of immigrants worldwide. Nations and communities are filled with people who have less in common, and who have become suspicious of one another. Many contexts have become potentially adversarial.

The significance of hospitality in the Old Testament has great potential to avert the potentially adversarial situation, because hospitality creates the platform for hermeneutic mediation, which promotes critical conversation that is mutually enhancing. The stimulated 'narrative approach' for reading the passage does not allow for a superficial theological-ethical recipe for the practice of hospitality. Rather, it is meant to provoke critical and wise discernment in carrying out one's theological, ethical and moral responsibilities towards the other. The writer felt obligated to end this article with a sermonic tone, namely that God is the owner of the earth. All human beings, irrespective of skin colour, tribe, nationality or geographic location and faith, are resident aliens who are enjoying the gracious offer of God's hospitality. Our moral and ethical duty is thus to reciprocate by making this earth 'a home for all'.

\section{Acknowledgements}

Thanks to Prof. H.L. Bosman (Stellenbosch University) and Prof. R.I. Murphy (Evangelical Church Winning All [ECWA] Theological Seminary, Jos) for their valuable insights and recommendations. To the Department of the Old Testament, Faculty of Theology, Stellenbosch University for privileges of a research fellow.

\section{Competing interests}

I declare that I have no financial or personal relationships which may have inappropriately influenced me in writing this article.

\section{Author's contributions}

I declare that I am the sole author of this research article. 


\section{Ethical consideration}

This article followed all ethical standards for carrying out research without direct contact with human or animal subjects.

\section{Funding information}

I wish to acknowledge the support of the Department of Old and New Testament, Faculty of Theology, Stellenbosch University for the privileges I enjoy as a research fellow.

\section{Data availability statement}

Data sharing is not applicable to this article as no new data were created or analysed in this study.

\section{Disclaimer}

I wish to express here that all the views expressed in this article, are my personal views and not the official position of the institutions to which I am associated with.

\section{References}

Arnold, B.T., 1998, Encountering the book of Genesis, Baker Books, Grand Rapids, MI. Bailey, R.C., 2010, 'Why do readers believe Lot?: Genesis 19 reconsidered', OTE, 23(3), 519-548, viewed 29 August 2019, from http://www.scielo.org.za/scieo. php?script=sci_arttext\&pid=S1010-99192010000300003.

Barton, J., 2002, Ethics and the Old Testament, 2nd edn., SCM, London.

Blenkinsopp, J., 2015, Abraham: The story of a life, Eerdmans, Grand Rapids, MI.

Bosman, H.L., 2018, 'Loving the neighbour and the resident alien in Leviticus 19 as ethical redefinition of holiness', OTE 31(3), 571-590. https://doi. org/10.17159/2312-3621/2018/v31n3a10

Boswell, J., 1980, Christianity, social tolerance and homosexuality, University of Chicago Press, Chicago, IL.

Carr, D.M., 2011, Introduction to the Old Testament: Sacred text and imperial context of the Hebrew Bible, John Wiley \& Sons, West Sussex.

Dell, K.J., 2009, 'Hospitality: Old Testament', in H.D. Betz, D.S. Browning, B. Janowski \& E. Jüngel, (eds.), Religion past and present: Encyclopedia of theology and religion, pp. 260-262, vol. 6, Brill, Leiden.

Fields, W.W., 1997, Sodom and Gomorrah: History and motif in biblical narrative, Sheffield Academic Press, Sheffield.
Fretheim, T.E, 1977, 'Theology of the major traditions in Genesis-Numbers', Review \& Expositor 74(3), 301-320, viewed 2 March 2016, from http://search.ebscohost. com.ez.sun.ac.za/login.aspx?direct=true\&db=rfh\&AN=ATLA0000762177\&site=eh com.ez.sun.ac.za/login.
ost-live \&scope $=$ site.

Gunkel, H., 1997, Genesis, transl. M.E. Biddle, Mercer University Press, Macon, GA.

Hamilton, V.P., 1995, The book of Genesis chapters 18-50, Eerdmans, Grand Rapids, MI. (New international commentary on the Old Testament).

Hobbs, T.R., 2001, 'Hospitality in the first testament and the "teleological fallacy"', Journal for the Study of the Old Testament 26(1), 3-30. https://doi. org/10.1177/030908920102600101

Köhler, L., Baumgartner, W., Stamm, J.J. \& Hartmann, B., 1994-2000, The Hebrew and Aramaic Lexicon of the Old Testament (HALOT), vol. I-IV, Brill, Leiden.

Lawrie, D., 2005, 'Approaches focusing on the text themselves', in L.C. Jonker \& D.L. (eds.), Fishing for Jonah anew: Various approaches to biblical interpretation, pp. $96 \mathrm{f}$., SUN Press, Stellenbosch.

Letellier, R.I., 1995, Day in Mamre, night in Sodom: Abraham and Lot in Genesis 18 and 19, Brill, Leiden.

Loader, J.A., 1990, A tale of two cities: Sodom and Gomorrah in the Old Testament Early Jewish and early Christian traditions, Peeters, Leuven.

Matthews, K.A., 2005, The new American commentary: Genesis 11:27-50:27, vol. 1b, Broadman \& Holman, Nashville, TN.

Matthews, V.H. 1992, 'Hospitality and hostility in Genesis 19 and Judges 19', A Journa of Bible and Theology 22(1), 3-11. https://doi.org/10.1177/014610799202200102

McKeown, J., 2008, Genesis, Eerdmans, Grand Rapids, MI.

Noort, E., 2004, 'For the sake of righteousness: Abraham's negotiations with YHWH as prologue to the Sodom narrative: Genesis 18:16-33', in E. Noort \& E. Tigchelaar (eds.), Sodom's sin and its interpretations, pp 1-15, Brill, Leiden.

Pardee, D., 2003, 'The 'Aqhatu Legend (1.103)' in W.W Hallo (ed.), The context of Scripture, vol. 1, pp. 343ff., Brill, Leiden.

Pezzoli-Olgiati, D., 2009, 'Hospitality', in H.D. Betz, D.S. Browning, B. Janowski. \& E. Jüngel, (eds.), Religion past and present: Encyclopedia of theology and religion, vol. 6, pp. 260-262, Brill, Leiden.

Robinson, J.C. 2007, 'Narrative', in S.E. Porter (ed.), Dictionary of biblical criticism and interpretation, pp. 236-237, Routledge, London.

Safren, J.D., 2012, 'Hospitality compared: Abraham and Lot as Hosts', in D. Lipton (ed.), Universalism and particularism at Sodom and Gomorrah, pp. 157-178, Atlanta, GA. (SBL 11).

Shryock, A., 2004, 'The new Jordanian hospitality: House, host, and guest in the culture of public display', Comparative Studies in Society and History 46(1), 35-62. https://doi.org/10.1017/S0010417504000039

Towner, W.S., 2001, Genesis, Westminster John Knox Press, Louisville, KY.

Von Rad, G., 1972, Genesis, transl. J.H. Marks, Westminster Press, Philadelphia, PA.

Waltke, B.K. \& Fredricks, C.J., 2001, Genesis: A commentary, Zondervan, Grand Rapids, MI.

Waltke, B.K. \& O'Connor, M., 1990, An introduction to biblical Hebrew syntax, Eisenbrauns, Winona Lake, IN

Westermann, C., 1985, Genesis 12-36: A commentary, transl. J.J. Scullion, Augsburg Publishing House, Minneapolis, MN.

Westfall, C.L., 2007, 'Narrative criticism', in S.E. Porter (ed.), Dictionary of biblical criticism and interpretation, pp. 237-239, Routledge, London. 